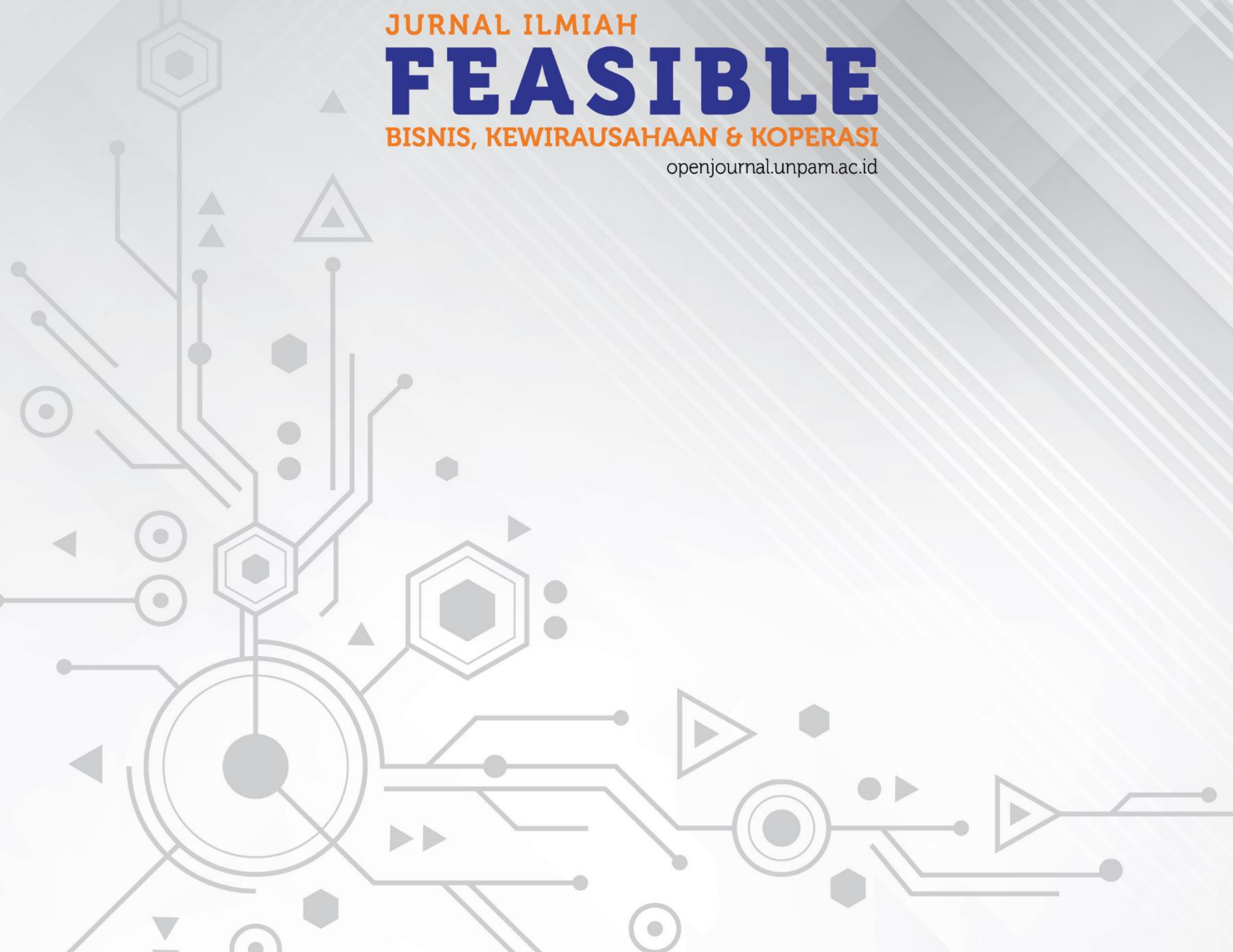




\title{
ANALISIS PENETAPAN TARIF KAMAR DAN \\ KUALITAS PELAYANAN TERHADAP KEPUASAN PELANGGAN PADA WISMA UNIVERSITAS TERBUKA
}

\author{
(Studi Kasus pada Wisma Universitas Terbuka) \\ Sulaiman'; Suhria Atmana ${ }^{2}$ \\ Podi Manajemen, Universitas Pamulang \\ dosen01902@unpam.ac.id; doseno1961@unpam.ac.id
}

\begin{abstract}
Abstrak
Studi ini dilakukan untuk mengetahui berapa tingkat penghunian kamar, sejauh mana tingkat kepuasan pelanggan dan apakah dalam penetapan tarif kamar serta kualitas pelayanan yang sudah diterapkan berpengaruh terhadap kepuasan pelanggan pada Wisma Universitas Terbuka. Metode pengumpulan data yang digunakan adalah kuesioner dan wawancara. Metode analisis data yang digunakan adalah analisis deskriptif dan analisis statistik teknik regresi linear berganda menggunakan aplikasi MS Excel. Hasil Analisa diperoleh persamaan regresi linear berganda $Y=1.360-0.018 X 1+0.705 X 2$. Uji parsial (uji $t$ ) menunjukkan bahwa kualitas layanan berpengaruh signifikan terhadap kepuasan pelanggan, sedangkan penetapam tarif kamar tidak berpengaruh secara signifikan terhadap kepuasan pelanggan. Uji simultan (uji F) menunjukkan bahwa penetapan tarif kamar dan kualitas pelayanan berpengaruh signifikan terhadap kepuasan pelanggan secara simultan dengan koefisien determinasi simultan $\left(R^{2}\right)$ sebesar $34,3 \%$.
\end{abstract}

Kata kunci: kualitas pelayanan, kepuasan pelanggan, tarif kamar.

\begin{abstract}
This study was conducted to find out the level of room occupancy, the extent to which the level of customer satisfaction and whether in determining the room rate and the quality of service that has been applied has an effect on customer satisfaction at Wisma Open University. Data collection methods used were questionnaires and interviews. Data analysis method used is descriptive analysis and statistical analysis of multiple linear regression techniques using the $M S$ Excel application. Analysis results obtained by multiple linear regression equation $Y=$ $1.360-0.018 X 1+0.705 X 2$. Partial test ( $t$ test) shows that service quality has a significant effect on customer satisfaction, while room rate fixers do not significantly influence customer satisfaction. Simultaneous test ( $F$ test) showed that the determination of room rates and service quality significantly influence customer satisfaction simultaneously with a simultaneous determination coefficient (R2) of $34.3 \%$.
\end{abstract}

Keywords: service quality, customer satisfaction, room rates.. 
JURNAL ILMIAH FEASIBLE: Bisnis, Kewirausahaan \& Koperasi, Vol.2.No.1 Februari 2020: 53-70

\section{PENDAHULUAN}

Universitas Terbuka (UT) adalah perguruan tinggi negeri di bawah Kementerian Riset, Teknologi, dan Pendidikan Tinggi yang menyelenggarakan pendidikan tinggi dengan sistem belajar jarak jauh, UT didirikan berdasarkan Keputusan Presiden Nomor 41 tahun 1984. Sebagai satuan kerja perguruan tinggi negeri, kegiatan operasional UT dibiayai dari anggaran APBN dan anggaran Penerimaan Negara Bukan Pajak (PNBP). Sesuai dengan perkembangan kebijakan pemerintah, mulai sejak tahun 2005 perguruan tinggi negeri yang sudah memenuhi persyaratan teknis dan administratif didorong untuk menjadi Instansi Pemerintah yang menerapkan Pola Pengelolaan Keuangan Badan Layanan Umum.

Pada tahun 2011, berdasarkan Keputusan Menteri Keuangan Nomor 268/KMK.05/2011, UT ditetapkan sebagai perguruan negeri yang menerapkan Pola Pengelolaan Keuangan Badan Layanan Umum (PKBLU) Penuh. Dengan status PKBLU Penuh, UT dituntut untuk meningkatkan kinerja keuangan dan memberikan pelayanan yang lebih berkualitas kepada mahasiswa dan stakeholders lain sehingga layanan UT menjadi lebih baik, lebih cepat, dan lebih relevan dengan tuntutan masyarakat. Disamping itu dengan status PKBLU UT diberikan fleksibiltas dalam pengelolaan keuangan. Dengan status BLU maka UT juga dituntut untuk mencari sumber dana lainnya selain sumber dana dari jasa layanan pendidikan melalui berbagai kerjasama dan melalui unit usaha.

Dalam struktur organisasi Universitas Terbuka yang ditetapkan berdasarkan Peraturan Menteri Riset, Teknologi dan Pendidikan Tinggi nomor 16 tahun 2017 terdapat unit kerja Badan Pengelola dan Pengembangan Usaha (BPPU) yang mempunyai tugas melaksanakan pengembangan unit usaha dan mengoptimalkan perolehan sumbersumber pendanaan universitas untuk mendukung pelaksanaan penerapan pengelolaan keuangan badan layanan umum UT. Salah satu unit usaha UT yang sudah berjalan adalah pengelolaan Wisma I, Wisma II dan Wisma III.

Berdasarkan hasil penulusuran awal diperoleh data tamu yang menginap di Wisma Universitas Terbuka tahun 2018 sebagai beriku

Tabel 1.1. Rekapitulasi Tamu Wisma Universitas Terbuka Tahun 2018

\begin{tabular}{|c|c|c|c|c|c|}
\hline No & $\begin{array}{l}\text { Bulan / } \\
\text { Tahuu }\end{array}$ & $\begin{array}{c}\text { Wisma } \\
1\end{array}$ & $\begin{array}{c}\text { Wiswa } \\
2\end{array}$ & $\begin{array}{c}\text { Wisma } \\
\mathbf{3}\end{array}$ & Jumlah \\
\hline 1 & Januari & 4 & 162 & 24 & 190 \\
\hline 2 & Februari & 46 & 175 & 111 & 332 \\
\hline 3 & Maret & 64 & 245 & 99 & 408 \\
\hline 4 & April & 49 & 116 & 100 & 265 \\
\hline 5 & Mei & 44 & 115 & 73 & 232 \\
\hline 6 & Juni & 2 & 20 & 1 & 23 \\
\hline 7 & Juli & 60 & 255 & 175 & 490 \\
\hline 8 & Agustus & 23 & 247 & 46 & 316 \\
\hline 9 & September & 67 & 265 & 168 & 500 \\
\hline 10 & Oktober & 18 & 181 & 113 & 312 \\
\hline 11 & November & 65 & 360 & 216 & 641 \\
\hline 12 & Desember & 17 & 139 & 69 & 225 \\
\hline & Jumlah & 459 & 2.280 & 1.195 & 3.934 \\
\hline
\end{tabular}

Sumber: Wisma Universitas Terbuka tahun 2018

Dari data tersebut nampak bahwa jumlah tamu yang menginap di Wisma Universitas Terbuka tahun 2018 belum maksimal jika dibandingkan dengan jumlah 
JURNAL ILMIAH FEASIBLE: Bisnis, Kewirausahaan \& Koperasi, Vol.2.No.1 Februari 2020: 53-70

kamar yang tersedia sebanyak 16 kamar di

Wisma I, 46 kamar di Wisma II dan 48 kamar di Wisma III.

Sebagai unit usaha BLU di lingkungan UT yang menjadi pertanyaan adalah apakah pengelolaan Wiswa Universitas Terbuka khususnya dalam hal penetapan tarif kamar serta penyediaan produk berupa kualitas pelayanan wiswa sudah sesuai dengan keingingan pelanggan sehingga memiliki daya saing yang tinggi sebagai jasa penginapan di wilayah Tangerang Selatan.

Disamping itu, pada umumnya unit bisnis yang dikelola oleh instansi di lingkungan pemerintah belum dapat memberikan sumber pendapatan yang obtimal sebanding dengan sarana dan prasaranan atau aset yang telah disediakan. Maka dari itu yang menjadi pertanyaan juga dalam studi ini adalah apakah tingkat hunian Wiswa Universitas Terbuka sudah maksimal sehingga dapat memberikan kontribusi terhadap pendapatan Badan Layanan Umum.

Berdasarkan latar belakang di atas, peneliti melakukan penelitan dengan judul:

"Analisis penetapan tarif kamar dan kualitas pelayanan terhadap kepuasan pelanggan pada Wisma Universitas Terbuka”.

\section{Rumusan Masalah}

Berdasarkan uraian latar belakang dan judul penelitian di atas dapat dirumuskan masalah penelitan sebagai berikut:

1. Bagaimanakah penetapan tarif kamar, kualitas pelayanan, dan kepuasan pelanggan pada Wisma Universitas

Terbuka.

2. Bagaimanakah pengaruh penetapan tarif kamar terhadap kepuasan pelanggan pada Wisma Universitas Terbuka.

3. Bagaimanakah pengaruh kualitas pelayanan terhadap kepuasan pelanggan pada Wisma Universitas Terbuka.

4. Bagaimanakah pengaruh penetapan tarif kamar dan kualitas pelayanan terhadap kepuasan pelanggan pada Wiswa Universitas Terbuka.

5. Bagaimanakah tingkat penghunian kamar Wisma Universitas Terbuka.

\section{Tujuan Penelitian}

Berdasarkan rumusan masalah di atas, tujuan penelitian ini adalah:

1. Untuk mengetahui penetapan tarif kamar, kualitas pelayanan dan kepuasan pelanggan pada Wiswa Universitas Terbuka.

2. Untuk mengetahui pengaruh penetapan kamar terhadap kepuasan pelanggan pada Wisma Universitas Terbuka.

3. Untuk megetahui pengaruh kualitas pelayanan terhadap kepuasan pelanggan pada Wisma Universitas Terbuka.

4. Untuk mengetahui pengaruh penetapan tarif kamar dan kualitas pelayanan terhadap kepuasan pelanggan para Wiswa Universitas Terbuka.

5. Untuk mengetahui tingkat penghunian kamar Wiswa Universitas Terbuka. 
JURNAL ILMIAH FEASIBLE: Bisnis, Kewirausahaan \& Koperasi, Vol.2.No.1 Februari 2020: 53-70

\section{Kajian Literatur}

\section{Badan Layanan Umum}

Satuan kerja (satker) instansi pemerintah yang proses bisnisnya melakukan penerimaan dana dari masyarakat sebagai Penerimaan Negara Bakan Pajak (PNBP) seperti rumah sakit umum pemerintah, perguruan tinggi negeri, balai latihan kerja dan lainnya, mulai sejak tahun 2005 melalui Peraturan Pemerintah Nomor 23 Tahun 2015 tentang Pengelolaan Badan Layanan Umum diberikan keleluasaan untuk menerapkan Pola Pengelolaan Keuangan Badan Layanan Umum (PKBLU).

Badan Layanan Umum, yang selanjutnya disebut BLU, adalah instansi di lingkungan Pemerintah yang dibentuk untuk memberikan pelayanan kepada masyarakat berupa penyediaan barang dan/atau jasa yang dijual tanpa mengutamakan mencari keuntungan dan dalam melakukan kegiatarnya didasarkan pada prinsip efisiensi dan produktivitas. Pola Pengelolaan Keuangan Badan Layanan Umum, yang selanjutnya disebut PPKBLU, adalah pola pengelolaan keuangan yang memberikan fleksibilitas berupa keleluasaan untuk menerapkan praktekpraktek bisnis yarg sehat untuk meningkatkan pelayanan kepada masyarakat dalam rangka memajukan kesejahteraan umum dan mencerdaskan kehidupan bangsa, sebagaimana diatur dalam Peraturan Pemerintah ini sebagai pengecualian dan ketentuan pengelolaan keuangan negara pada umumnya (PP 23
Tahun 2005; 2). BLU bertujuan untuk meningkatkan pelayanan kepada masyarakat dalam rangka memajukan kesejahteraan umum dan mencerdaskan kehidupan bangsa dengan memberikan fleksibilitas dalam pengelolaan keuangan berdasarkan prinsip ekonomi dan produktivitas, dan penerapan praktek bisnis yang sehat (PP 23 Tahun 2005; 4).

Dengan menerapkan PPKBLU, maka perguruan tinggi negeri atau rumah sakit pemerintah, dan instansi pemerintah lainnya dapat menggunakan secara langsung pendapatan BLU untuk belanja operasional dan belanja pengembangan sesuai dengan Rencana Bisnis Anggaran tanpa harus disetor ke Kas Negara terlebih dahulu. Kemudian secara periodik minimal tiga bulan sekali pendapatan dan belanja BLU tersebut dilaporkan untuk dicatat sebagai pendapatan dan belanja negara melalui Kantor Pelayanan Perbendaharaan Negara (KPPN) setempat. Dengan menerapkan PPKBLU lembaga/instansi pemerintah dapat membentuk unit-unit usaha dalam rangka meningkatkan pendapatan BLU sebagaimana diatur dalam Pasal 27 ayat (2) PP Nomor 23 Tahun 2005 "Laporan keuangan unit-unit usaha yang diselenggarakan oleh BLU dikonsolidasikan dalam laporan keuangan sebagaimana dimaksud pada ayat (1) yaitu Laporan Keuangan BLU”. Unit usaha pada satker BLU berperan untuk menambah pendapatan lainnya di luar pendapatan jasa layanan guna meningkatkan kinerja keuangan BLU. 


\section{Penentuan Harga}

Dalam situasi persaingan usaha yang sangat ketat penentuan harga suatu produk barang atau jasa harus sangat cermat dan hati-hati, karena penentuan harga secara langsung akan berpengaruh terhadap kelangsungan bagi perusahaan/unit usaha. Banyak faktor yang dapat mempengaruhi terjadinya harga, menurut Basu Swastha Dharmmesta (2016: 7.5) "terjadinya harga tidak hanya terkait dengan kondisi internal perusahaan, tetapi juga faktor di luar perusahaan. Faktorfaktor tersebut adalah: (1) kondisi perekonomian, (2) penawaran dan permintaan, (3) elastisitas permintaan, (4) persaingan, (5) biaya, (6) tujuan manajer, dan (7) pengawasan pemerintah". Sedangkan menurut Machfoedz (2005: 136) "penetapan harga dipengaruhi oleh berbagai faktor, baik faktor internal maupun faktor eksternal. Faktor internal meliputi tujuan pemasaran perusahaan, strategi bauran pemasaran, biaya, dan metode penetapan harga. Sedangkan faktor eksternal meliputi sifat pasar dan permintaan, persaingan, dan elemen lingkungan yang lain".

Setiap penjual atau penyedia jasa dalam menetapkan harga mempunyai tujuan yang berlainan tergantung dari orientasi bisnisnya. Menurut Machfoedz (2005: 139) "tujuan penetapan harga meliputi (1) orientasi laba: mencapai target baru, dan meningkatkan laba; (2) orientasi penjualan: meningkatkan volume penjualan, dan mempertahankan atau mengembangkan pangsa pasar". Kemudian menurut Tjiptono (2002) tujuan penetapan harga adalah: "1) Berorientasi laba yaitu bahwa setiap perusahaan selalu memilih harga yang dapat menghasilkan laba yang paling tinggi: 2) Berorientasi pada volume yaitu penetapan harga berorientasi pada volume tertentu; 3) Berorientasi pada citra (image) yaitu bahwa image perusahaan dapat dibentuk melalui harga; 4) Stabilisasi harga yaitu penetapan harga yang bertujuan untuk mempertahankan hubungan yang stabil antara harga perusahaan dengan harga pemimpin pasar (market leader); dan 5) Tujuan lainnya yaitu menetapkan harga dengan tujuan mencegah masuknya pesaing, mempertahankan loyalitas konsumen, mendukung penjualan ulang atau menghindari campur tangan pemerintah".

Dimensi harga menurut Mursid (2014:83-84), meliputi:

1. "Cost oriented pricing, adalah penetapan harga yang semata-mata untuk memperhitungkan biaya-biaya dan tidak berorentasi pada pasar, terdiri dari dua macam yaitu: (a) Mark up pricing dan cost plus pricing cara penetapan harga yang sama, yaitu menambahkan biaya perunit dengan laba yang diharapkan. Mark up pricing digunakan dikalangan pedagang pengecer sedangkan cost plus pricing digunakan oleh manufacturer. (b) Target pricing, yaitu suatu penetapan harga jual berdasarkan target rate of return dari biaya total yang dikeluarkan ditambah 
JURNAL ILMIAH FEASIBLE: Bisnis, Kewirausahaan \& Koperasi, Vol.2.No.1 Februari 2020: 53-70

laba yang diharapkan pada volume penjualan yang diperkirakan;

2. Demand oriented pricing, penentuan harga dengan mempertimbangkan keadaan permintan, keadaan pasar dan keinginan konsumen, terdiri dari: (a) Perceived value pricing, yaitu berapa nilai produk dalam pandangan konsumen terhadap yang dihasilkan perusahaan. (b) Demand differential pricing atau price discrimination, yaitu penetapan harga jual produk dua macam harga atau lebih;

3. Competition oriented pricing, menetapkan harga jual yang berorientasi pada pesaing, terdiri dari: (a) Going rate pricing, suatu penetapan harga dimana perusahaan berusaha menetapkan harga setingkat dengan rata-rata industri. (b) Sealed bid pricing, yaitu suatu penetapan harga didasarkan pada penawaran yang diajukan pedagang.

Untuk mengukur apakah harga yang telah ditetapkan sudah dianggap layak dapat dipertahankan atau perlu dilakukan penyesuaian maka perlu dilakukan pengukuran dengan menggunakan berbagai indikator. Indikator harga menurut Mursid (2014:83-84) adalah sebagai berikut: “1) Harga yang kompetitif yaitu harga yang ditawarkan lebih kompetitif dari pesaing; 2) Kesesuaian harga dengan harga pasar yaitu kesesuaian harga dengan harga yang berlaku di wilayah pemasaran; 3) Kesesuaian harga dengan kualitas produk yaitu harga yang ditawarkan sesuai dengan kualitas produk; 4) Angsuran yaitu pembayaran yang bisa diangsur sampai jangka waktu tertentu.

\section{Kualitas Pelayanan}

Produk dapat digolongkan berdasarkan beberapa pendekatan, antara lain (1) pendekatan yang didasarkan pada dimensi kepuasan segera dan kesejahteraan konsumen jangka panjang, (2) pendekatan yang didasarkan pada tujuan pemakiannya oleh si pemakai. Berdasarkan pendekatan (1), produk dapat digolongkan menjadi empat golongan seperti yang dikemukan oleh Kotler (1978) yaitu:

a. "Produk yang bermanfaat (salutory product), yaitu produk yang mempunyai daya penarik rendah tetapi dapat memberikan manfaat yang tinggi kepada konsumen dalam jangka panjang.

b. Produk yang kurang sempurna (deficient product), yaitu produk yang tidak mempunyai daya penarik yang tinggi maupun kualitas yang bermanfaat.

c. Produk yang menyenangkan (pleasing product), yaitu produk yang dapat segera memberikan kepuasan tetapi berakibat buruk bagi konsumen dalam jangka panjang.

d. Produk yang sangat diperlukan (desirable product), yaitu produk yang dapat memberikan kepuasan dengan segera dan sangat bermanfaat dalam jangka Panjang”.

Produk berupa jasa seperti halnya jasa penginapan bertujuan untuk memberi- 
JURNAL ILMIAH FEASIBLE: Bisnis, Kewirausahaan \& Koperasi, Vol.2.No.1 Februari 2020: 53-70

kan kepuasan kepada konsumen/tamu selama konsumen tersebut barada di lingkungan penginapan (kamar maupun lingkungan sekitar kamar). Produk jasa penginapan dapat tergolong sangat diperlukan dan memberikan kepuasan dengan segera dan sangat bermanfaat dalam jangka panjang apabila memenui berbagai indikator kualitas pelayanan jasa penginapan yang tinggi. Kualitas pelayanan menurut James dan Mona Fitzsimmons yang dikutip oleh Sulastiyoso (1999) dijelaskan bahwa tamu akan menilai kualitas pelayanan melalui lima prinsip pelayanan yaitu:

1. "Reliability, adalah kemampuan untuk memberikan secara tepat dan benar jenis pelayanan yang telah dijanjikan kepada tamu.

2. Responsive, yaitu kesadaran atau keinginan untuk cepat bertindak membantu tamu dan memberikan pelayanan yang tepat waktu.

3. Assurance, adalah pengetahuan dan kesopansantunan serta kepercayaan dari para pegawai hotel.

4. Emphaty, yaitu memberikan perhatian pada individu tamu secara khusus.

5. Tangible, yaitu sesuai yang nampak atau yang nyata seperti penampilan pegawai dan fasilitas peralatan yang menunjang pelaksanaan pelayanan”.

\section{Kepuasan Pelanggan}

Memuaskan kebutuhan konsumen/ pelanggan adalah keinginan setiap perusahaan. Selain faktor penting bagi kelangsungan hidup perusahaan, memuaskan kebutuhan konsumen dapat meningkatkan keunggulan dalam persaingan. Konsumen yang puas terhadap suatu produk dan jasa pelayanan cenderung untuk membeli kembali produk dan menggunakan kembali jasa pada saat kebutuhan yang sama muncul kembali dikemudian hari. Hal ini berarti kepuasan merupakan faktor kunci bagi konsumen dalam melakukan pembelian ulang yang merupakan porsi terbesar dari volume penjualan perusahaan.

Menurut Khotler (2000:36) definisi kepuasan adalah "perasaan seseorang mengenai kesenangan atau hasil yang mengecewakan dari membandingkan penampilan produk yang telah disediakan (hasil) dalam yang berhubungan dengan harapan si pelanggan”. Dengan demikian kepuasan pelanggan sepenuhnya bukan berarti memberikan kepada apa yang menurut kita keinginan dari mereka, tetapi apa yang sesungguhnya mereka inginkan serta kapan dan bagaimana mereka inginkan. Atau secara singkat adalah memenuhi kebutuhan pelanggan. Sedangkan Setyawan dan Susila dalam Usahawan (2004:31), "Kepuasan pelanggan merupakan evaluasi spesifik terhadap keseluruhan pelayanan yang diberikan pemberi jasa, sehingga kepuasan pelanggan hanya dapat dinilai berdasarkan pengalaman yang pernah dialami saat proses pemberian pelayanan". Kepuasan pelanggan ditentukan oleh pelayanan yang diberikan baik secara tangible maupun intangible, dalam hal ini penilaian 
JURNAL ILMIAH FEASIBLE: Bisnis, Kewirausahaan \& Koperasi, Vol.2.No.1 Februari 2020: 53-70

dilakukan oleh pelanggan mengenai kategori jasa yang diberikan.

Dalam menentukan tingkat kepuasan konsumen, terdapat lima faktor utama yang harus diperhatikan oleh perusahaan (Lupyoadi, 2001) yaitu:

a. "Kualitas produk. Konsumen akan merasa puas bila hasil evaluasi mereka menunjukkan bahwa produk yang mereka gunakan berkualitas.

b. Kualitas pelayanan, terutama untuk industri jasa. Konsumen akan merasa puas bila mereka mendapatkan pelayanan yang baik atau yang sesuai dengan yang diharapkan.

c. Emosional. Konsumen akan merasa bangga dan mendapatkan keyakinan bahwa orang lain akan kagum terhadap dia bila menggunakan produk dengan merek tertentu yang cenderung mempunyai tingkat kepuasan yang lebih tinggi. Kepuasan yang diperoleh bukan karena kualitas dari produk tetapi nilai sosial yang membuat konsumen menjadi puas terhadap merek tertentu.

d. Harga. Produk yang mempunyai kualitas yang sama tetapi menetapkan harga yang yang relatif murah akan memberikan nilai yang lebih tinggi kepada konsumennya.

e. Biaya. Konsumen yang tidak perlu mengeluarkan biaya tambahan atau tidak perlu membuang waktu untuk mendapatkan suatu produk atau jasa cenderung puas terhadap produk atau jasa itu”.
Menurut Hawkins dan Lonney dikutip dalam bukunya Tjiptono (2004:101) atribut pembentuk kepuasan terdiri dari:

a. "Kesesuaian harapan

Merupakan tingkat kesesuaian antara kinerja produk yang diharapkan oleh pelanggan dengan yang dirasakan oleh pelanggan, meliputi :

1) Produk yang diperoleh sesuai atau melebihi dengan yang diharapkan.

2) Pelayanan oleh karyawan yang diperoleh sesuai atau melebihi dengan yang diharapkan.

3) Fasilitas penunjang yang didapat sesuai atau melebihi dengan yang diharapkan.

b. Minat berkunjung kembali

Merupakan kesedian pelanggan untuk berkunjung kembali atau melakukan pembelian ulang terhadap produk terkait, meliputi :

1) Berminat untuk berkunjung kembali karena pelayanan yang diberikan oleh karyawan memuaskan.

2) Berminat untuk berkunjung kembali karena nilai dan manfaat yang diperoleh setelah mengkonsumsi produk.

3) Berminat untuk berkunjung kembali karena fasilitas penunjang yang disediakan memadai.

c. Kesediaan merekomendasikan

Merupakan kesediaan pelanggan untuk merekomendasikan produk yang telah dirasakannya kepada teman atau keluarga, meliputi : 
JURNAL ILMIAH FEASIBLE: Bisnis, Kewirausahaan \& Koperasi, Vol.2.No.1 Februari 2020: 53-70

1) Menyarankan teman atau kerabat untuk membeli produk yang ditawarkan karena pelayanan yang memuaskan.

2) Menyarankan teman atau kerabat untuk membeli produk yang ditawarkan karena fasilitas penunjang yang disediakan memadai.

3) Menyarankan teman atau kerabat untuk membeli produk yang ditawarkan karena nilai atau manfaat yang didapat setelah mengkonsumsi sebuah produk jasa”.

\section{Kerangka Berfikir}

Sebagai dasar untuk menganalisis dan mengambil kesimpulan dalam studi ini, secara teoritis digambarkan kerangka pemikiran sebagai berikut:

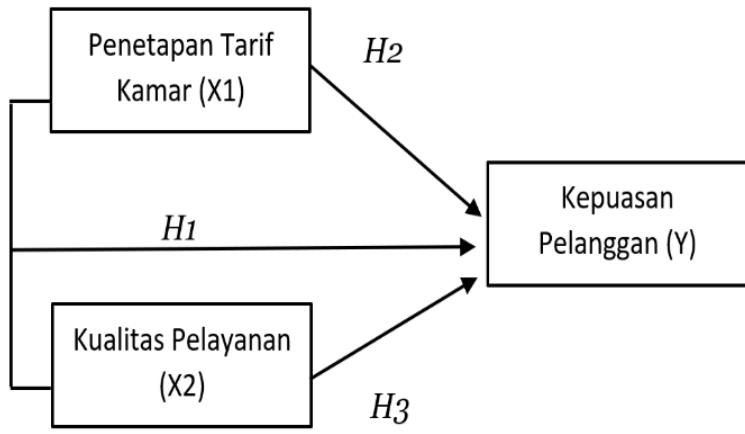

Gambar 1.1. Kerangka Pemikiran

Dari Gambar 1.1 di atas dapat dijelaskan bahwa hal tersebut merupakan kerangka pemikiran teoritis sebagai dasar dalam penelitian ini, dimana $\mathrm{H} 1$ diartikan sebagai pengaruh variabel Penetapan Tarif Kamar, dan Kualitas Pelayanan yang secara simultan diduga mempengaruhi terhadap Kepuasan Pelanggan. H2 diartikan sebagai pengaruh variabel Penetapan Tarif Kamar yang secara parsial diduga mempengaruhi terhadap Kepuasan Pelanggan. H3 diartikan sebagai pengaruh variabel Kualitas Pelayanan yang secara parsial diduga mempengaruhi terhadap Kepuasan Pelanggan.

\section{METODE \\ Disain Penelitian}

Metode yang digunakan untuk penelitian ini adalah metode kualitatif dan kuantitatif. Metode kualitatif untuk mengetahui posisi bisnis unit usaha dalam hal ini Wisma Universitas Terbuka berdasarkan faktor internal dan faktor eksternal serta penilaian terhadap setiap indikator. Sedangkan metode kuantitatif merupakan pendekatan yang menyangkut pendugaan parameter, pengujian hipotesis, pembentukan selang kepercayaan, dan hubungan antara dua sifat (peubah) atau lebih bagi parameter-parameter yang mempunyai sebaran (distribusi normal) tertentu yang diketahui. Tujuan metode kuantitatif ini adalah untuk melihat pengaruh kebijakan penetapan tarif dan kualitas pelayanan terhadap kepuasan pelanggan pada Wiswa Universitas Terbuka. Selanjutnya dianalisis dengan menggunakan metode analisis statistik teknik regresi berganda. Unit analisis pada penelitian ini adalah pelanggan Wiswa Univeritas Terbuka.

\section{Populasi dan Sampel}

Populasi dalam penelitian ini adalah pelanggan Wisma Universitas Terbuka, 
Tangerang Selatan. Pengambilan sampel dilakukan dengan menggunakan non probability sampling yakni setiap anggota populasi tidak memiliki kesempatan atau peluang yang sama sebagai sampel. Teknikteknik yang termasuk ke dalam non probability ini antara lain: sampling sistematis, sampling kuota, sampling insidential, sampling purposive, sampling jenuh, dan snowball sampling. Dalam penelitian ini menggunakan sampling insidential merupakan teknik penentuan sampel secara kebetulan, atau siapa saja yang kebetulan (insidential) bertemu dengan peneliti dalam jangka waktu tertentu yang dianggap cocok dengan karakteristik sampel yang ditentukan dijadikan sampel. Adapun yang menjadi sampel dalam penelitian ini adalah tamu yang menginap pada Wisma Universitas Terbuka kurang lebih sebanyak 55 orang yang secara kebetulan dapat dimintai keterangan mulai tanggal 17 Juni 2019 sampai dengan 5 Juli 2019.

\section{Metode Pengumpulan Data}

Dalam penelitian ini proses pengumpulan data menggunakan 3 (tiga) metode yang saling berkaitan dan melengkapi yaitu: 1) wawnacara, 2) dokumentasi dan 3) angket/kuesioner.

\section{Metode Analisis Data}

Analisis data adalah "proses mencari dan menyusun secara sistematis data yang diperoleh dari hasil wawancara, catatan lapangan, dan bahan-bahan lain, sehingga dapat mudah dipahami, dan temuannya dapat diinformasikan kepada orang lain" (Bogdan dalam Sugiyono, 2013:244). Sedangkan menurut Suprayogo analisis data adalah "rangkaian kegiatan penelaahan, pengelompokan, sistematisasi, penafsiran dan verifikasi data agar sebuah fenomena memiliki nilai sosial, akademis dan ilmiah". Dalam penelitian menggunakan dua cara teknik analisis data yaitu analisis data deskriptif dan analisis data satistik.

\section{HASIL dan PEMBAHASAN}

\section{Hasil Penelitian}

\section{Gambaran Umum Wisma Universitas Terbuka}

a. Fasilitas Wiswa Univeritas Terbuka. Universitas Terbuka memiliki tiga Gedung Wisma yang dinamakan Wisma I, Wisma II dan Wisma III. Setiap Wiswa UT memiliki fasilitas ruang kamar ber AC, ruang siding, mushola, Wifi-id dan Hotspot. Diluar wisma terdapat fasilitas pendukung lain seperti sport centre, UT Convention Centre (UTCC), Gazebo di tengah danau buatan, dan Gedung Serba Guna.

b. Tarif Sewa Kamar.

Tarif atau harga sewa kamar wisma Univeritas Terbuka ditetapkan berdasarkan Surat Keputusan Rektor Universitas Terbuka Nomor: 46 tahun 2018. Penetapan tarif oleh Rektor tersebut mengacu pada Peraturan Menteri Kuangan Republik Indonesia Nomor 114/PMK.05/2014 tentang Tarif Layanan Badan Layanan Umum Universitas Terbuka pada Kementrian 
JURNAL ILMIAH FEASIBLE: Bisnis, Kewirausahaan \& Koperasi, Vol.2.No.1 Februari 2020: 53-70

Pendidikan dan Kebudayaan. Adapun besaran tarif sewa kamar per hari adalah sebagai berikut:

Tabel 1.2 Tarif Layanan Wiswa Universitas Terbuka

\begin{tabular}{|c|c|c|c|c|}
\hline No & $\begin{array}{l}\text { Lokasi } \\
\text { Wiswa }\end{array}$ & Jenis & $\begin{array}{l}\text { Harga } \\
\text { Sewa }\end{array}$ & Ket. \\
\hline & \multicolumn{4}{|l|}{ Kamar } \\
\hline 1 & Wiswa 1 & $\begin{array}{l}\text { Standard } \\
3 \text { bed }\end{array}$ & $\begin{array}{l}\text { Rp550.000 / } \\
\text { hari }\end{array}$ & Sarapan \\
\hline 2 & Wisma 1 & $\begin{array}{l}\text { Standard } \\
4 \text { bed }\end{array}$ & $\begin{array}{l}\text { Rp700.000 / } \\
\text { hari }\end{array}$ & Sarapan \\
\hline 3 & Wisma 2 & $\begin{array}{l}\text { Deluxe } 2 \\
\text { bed }\end{array}$ & $\begin{array}{l}\text { Rp550.000 / } \\
\text { hari }\end{array}$ & Sarapan \\
\hline 4 & Wiswa 2 & $\begin{array}{l}\text { Junior } \\
\text { Suite } 1 \\
\text { bed }\end{array}$ & $\begin{array}{l}\text { Rp100.000 / } \\
\text { hari }\end{array}$ & Sarapan \\
\hline 5 & Wiswa 3 & $\begin{array}{l}\text { Deluxe } 2 \\
\text { bed }\end{array}$ & $\begin{array}{l}\text { Rp550.000 / } \\
\text { hari }\end{array}$ & Sarapan \\
\hline 6 & Wiswa 3 & $\begin{array}{l}\text { Deluxe } 1 \\
\text { bed }\end{array}$ & $\begin{array}{l}\text { Rp600.000 / } \\
\text { hari }\end{array}$ & Sarapan \\
\hline \multirow[t]{2}{*}{7} & $\begin{array}{l}\text { Wisma } 1, \\
2,3\end{array}$ & $\begin{array}{l}\text { Extra } \\
\text { bed }\end{array}$ & $\begin{array}{l}\text { Rp170.000 / } \\
\text { hari }\end{array}$ & Sarapan \\
\hline & \multicolumn{2}{|c|}{ Ruang Sidang } & & \\
\hline 1 & Wisma 1 & Lantai 2 & $\begin{array}{l}\text { Rp1.000.000 } \\
\text { / 4jam }\end{array}$ & $\begin{array}{l}200 \\
\text { kursi }\end{array}$ \\
\hline 2 & Wisma 2 & $\begin{array}{l}\text { Lantai } \\
\text { dasar }\end{array}$ & $\begin{array}{l}\text { Rp1.000.000 } \\
\text { / 4jam }\end{array}$ & $\begin{array}{l}70 \\
\text { kursi }\end{array}$ \\
\hline \multirow[t]{2}{*}{3} & Wisma 3 & $\begin{array}{l}\text { Lantai } \\
\text { dasar }\end{array}$ & $\begin{array}{l}\text { Rp1.000.000 } \\
\text { / 4jam }\end{array}$ & $\begin{array}{l}60 \\
\text { kursi }\end{array}$ \\
\hline & \multicolumn{2}{|c|}{$\begin{array}{l}\text { Kelebihan } \quad \text { jam } \\
\text { pemakaian }\end{array}$} & $25 \% /$ jam & \\
\hline 4 & Wisma 1 & $\begin{array}{l}\text { Lantai } \\
\text { dasar }\end{array}$ & $\begin{array}{l}\text { Rp800.000 / } \\
\text { 4jam }\end{array}$ & $\begin{array}{l}50 \\
\text { kursi }\end{array}$ \\
\hline 5 & Wisma 2 & Lantai 2 & $\begin{array}{l}\text { Rp800.000 / } \\
\text { 4jam }\end{array}$ & $\begin{array}{l}20 \\
\text { kursi }\end{array}$ \\
\hline 6 & Wisma 2 & Lantai 3 & $\begin{array}{l}\text { Rp800.000 / } \\
\text { 4jam }\end{array}$ & $\begin{array}{l}20 \\
\text { kursi }\end{array}$ \\
\hline & $\begin{array}{l}\text { Kelebihan } \\
\text { pemakaian }\end{array}$ & jam & $20 \% / j a m$ & \\
\hline
\end{tabular}

c. Tingkat Hunian

Jumlah tamu (orang/hari) yang menginap di Wisma Universitas Terbuka selama kurun waktu mulai dari bulan Januari 2018 sampai dengan bulan Mei 2019 adalah sebagai berikut:

Tabel 1.3 Tingkat Hunian Wisma Universitas Terbuka

\begin{tabular}{|l|l|r|r|r|r|}
\hline No & $\begin{array}{c}\text { Bulan / } \\
\text { Tahun }\end{array}$ & $\begin{array}{c}\text { Wisma } \\
\mathbf{1}\end{array}$ & $\begin{array}{c}\text { Wiswa } \\
\mathbf{2}\end{array}$ & $\begin{array}{c}\text { Wisma } \\
\mathbf{3}\end{array}$ & Jumlah \\
\hline \multicolumn{5}{|c|}{ Tahun 2018} \\
\hline 1 & Januari & 4 & 162 & 24 & 190 \\
\hline 2 & Februari & 46 & 175 & 111 & 332 \\
\hline 3 & Maret & 64 & 245 & 99 & 408 \\
\hline 4 & April & 49 & 116 & 100 & 265 \\
\hline 5 & Mei & 44 & 115 & 73 & 232 \\
\hline 6 & Juni & 2 & 20 & 1 & 23 \\
\hline 7 & Juli & 60 & 255 & 175 & 490 \\
\hline 8 & Agustus & 23 & 247 & 46 & 316 \\
\hline 9 & September & 67 & 265 & 168 & 500 \\
\hline 10 & Oktober & 18 & 181 & 113 & 312 \\
\hline
\end{tabular}

\begin{tabular}{|c|c|c|c|c|c|}
\hline No & $\begin{array}{l}\text { Bulan / } \\
\text { Tahun }\end{array}$ & $\begin{array}{c}\text { Wisma } \\
1\end{array}$ & $\begin{array}{c}\text { Wiswa } \\
2\end{array}$ & $\begin{array}{c}\text { Wisma } \\
\mathbf{3}\end{array}$ & Jumlah \\
\hline 11 & November & 65 & 360 & 216 & 641 \\
\hline 12 & Desember & 17 & 139 & 69 & 225 \\
\hline & Jumlah & 459 & 2.280 & 1.195 & 3.934 \\
\hline \multicolumn{6}{|c|}{ Tahun 2019} \\
\hline 1 & Januari & 28 & 84 & 26 & 138 \\
\hline 2 & Februari & 25 & 170 & 163 & 358 \\
\hline 3 & Maret & 28 & 206 & 165 & 399 \\
\hline 4 & April & 27 & 131 & 131 & 289 \\
\hline 5 & Mei & 4 & 108 & 102 & 214 \\
\hline & Jumlah & 112 & 699 & 587 & 1.398 \\
\hline
\end{tabular}

\section{Profil Responden}

Profil responden adalah hasil dari survey pendapat terhadap objek melalu pengisian kuesioner/angket. Dalam penelitian ini terkumpul isian kuesioner sebanyak 55 orang responden. Responden mengisi kuesioner secara bebas tanpa diberikan diarahkan untuk kepentingan tertentu. Gambaran responden menurut jenis kelamin, tingkat pendidikan, pekerjaan dan usia sebagai berikut:

Tabel 1.4. Jenis Pekerjaan Responden

\begin{tabular}{|c|l|c|c|}
\hline No & $\begin{array}{c}\text { Tingkat } \\
\text { Pendidikan }\end{array}$ & Frekuensi & Persen (\%) \\
\hline 1 & Pegawai Negeri & 24 & $44 \%$ \\
\hline 2 & Wiraswasta & 3 & $5 \%$ \\
\hline 3 & Pegawai Swasta & 16 & $29 \%$ \\
\hline 4 & Lain-lain & 12 & $22 \%$ \\
\hline & Jumlah & 55 & $100 \%$ \\
\hline
\end{tabular}

Tabel 1.5. Tingkat Pendidikan Responden

\begin{tabular}{|c|l|c|c|}
\hline No & \multicolumn{1}{|c|}{$\begin{array}{c}\text { Tingkat } \\
\text { Pendidikan }\end{array}$} & Frekuensi & Persen (\%) \\
\hline 1 & SLTA & 4 & $7 \%$ \\
\hline 2 & Strata 1 & 30 & $55 \%$ \\
\hline 3 & Strata 2 & 14 & $25 \%$ \\
\hline 4 & Strata 3 & 6 & $11 \%$ \\
\hline 5 & Lain-lain & 1 & $2 \%$ \\
\hline & Jumlah & 55 & $100 \%$ \\
\hline
\end{tabular}

\section{Uji Validitas dan Reliabilitas}

a. Validitas Instrumen

Uji validitas kuesioner menggunakan rumus korelasi Product Moment dengan bantuan aplikasi MS Exel diperoleh hasil sebagai berikut: 
JURNAL ILMIAH FEASIBLE: Bisnis, Kewirausahaan \& Koperasi, Vol.2.No.1 Februari 2020: 53-70

Tabel 1.6. Hasil Validasi Item Variabel Tarif Kamar

\begin{tabular}{|c|r|r|r|r|r}
\hline Variabel & \multicolumn{1}{|c|}{ X1.1 } & X1.2 & X1.3 & X1.4 & Total \\
\hline X1.1 & 1 & & & & \\
\hline$X 1.2$ & 0.71632 & 1 & & & \\
\hline$X 1.3$ & 0.55 & 0.4722 & 1 & & \\
\hline X1.4 & 0.06734 & -0.00212 & 0.033 & 1 & \\
\hline Total & 0.81409 & 0.74933 & 0.69474 & 0.49461 & 1 \\
\hline
\end{tabular}

Tabel 1.7. Hasil Vadasi Item

Variabel Kualitas Pelayanan

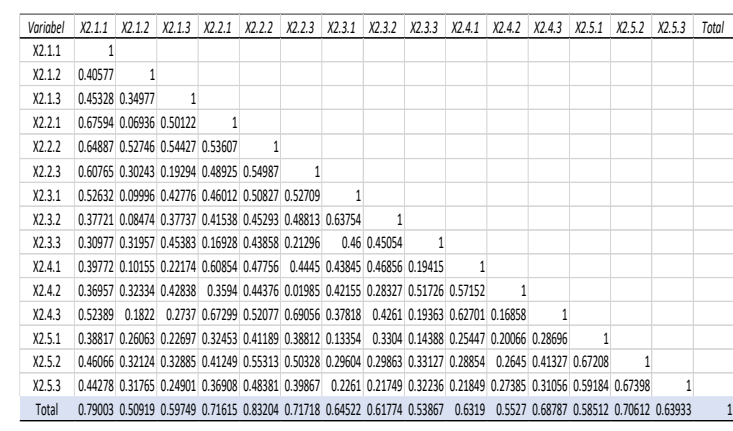

Tabel 1.8. Hasil Vadasi Item

Variabel Kepuasan Pelanggan

\begin{tabular}{|c|r|r|r|r|}
\hline & \multicolumn{1}{|c|}{ Y1 } & \multicolumn{1}{|c|}{ Y2 } & \multicolumn{1}{c|}{ Y3 } & \multicolumn{1}{|c|}{ Total } \\
\hline Y1 & 1 & & & \\
\hline Y2 & 0.65834 & 1 & & \\
\hline Y3 & 0.69925 & 0.58964 & 1 & \\
\hline Total & 0.89039 & 0.8617 & 0.87326 & 1 \\
\hline
\end{tabular}

Konsultasi pada r-tabel dengan $\mathrm{n}=55$ taraf kepercayaan 95\% adalah 0.266, rhitung semua item instrumen varibel bebas maupun variabel terikat lebih besar dari $\mathrm{r}$ tabel, dengan demikian maka semua item instrumen kepuasan pelanggan dapat dinyatakan valid.

\section{b. Reliabilitas Instrumen}

Uji reliabilitas kuesioner menggunakan rumus korelasi Sperman Brown dengan langkah sebagai berikut:

1) Dengan metode splith-half Spearman Brown, diperoleh hasil koefisien korelasi berikut:
Tabel 1.9. Hasil uji reliabilitas

\begin{tabular}{|l|r|r|}
\hline & Item Ganjl & Item Genap \\
\hline Item Ganjil & 1 & \\
\hline Item Genap & 0.82815319 & 1 \\
\hline
\end{tabular}

2) Dengan rumus Sperman Brown diperoleh R-hitung $=0.906$.

Kriteria: jika hasil analisis korelasinya lebih besar atau sama dengan 0.80 maka instrument penelitian dinyatakan reliabel. R-hitung $=0.906$ lebih besar dari 0.80 , dengan demikian dapat dinyatakan bahwa kuesioner yang dipakai dalam penelitian ini bersifat Reliabel.

\section{Analisis Data Deskriptif}

1. Penilaian Indikator Variabel

Gambaran penilaian terhadap setiap indikator variabel bebas maupun variabel terikat dengan mengacu pada tabel kriteria tanggapan responden adalah sebagai berikut.

Tabel 1.10. Penilaian Variabel

Penetapan Tarif Kamar (X1)

\begin{tabular}{|c|c|c|c|c|c|c|c|c|}
\hline \multirow{2}{*}{$\begin{array}{c}\text { Krite } \\
\text { ria }\end{array}$} & \multicolumn{4}{|c|}{ Jawaban Responden } & \multirow{2}{*}{ Jumlah } & $\begin{array}{c}\text { Mean } \\
\text { Skor }\end{array}$ & Ket \\
\cline { 2 - 7 } X1.1 & 14 & 35 & 5 & 1 & 0 & 55 & 4.13 & Baik \\
\hline X1.2 & 11 & 36 & 8 & 0 & 0 & 55 & 4.05 & Baik \\
\hline X1.3 & 39 & 1 & 2 & 0 & 0 & 42 & 3.73 & Baik \\
\hline X1.3 & 29 & 8 & 3 & 0 & 0 & 40 & 3.38 & Baik \\
\hline Total & $\mathbf{9 3}$ & $\mathbf{8 0}$ & $\mathbf{1 8}$ & $\mathbf{1}$ & $\mathbf{0}$ & $\mathbf{1 9 2}$ & $\mathbf{3 . 8 2}$ & Baik \\
\hline
\end{tabular}

Tabel 1.11. Penilaian Variabel

Kualitas Pelayanan (X2)

\begin{tabular}{|c|c|c|c|c|c|c|c|c|}
\hline \multirow{2}{*}{$\begin{array}{c}\text { Krite } \\
\text { ria }\end{array}$} & \multicolumn{5}{|c|}{ Jawaban Responden } & \multirow{2}{*}{ Jumlah } & \multirow{2}{*}{$\begin{array}{c}\text { Mean } \\
\text { Skor }\end{array}$} & \multirow{2}{*}{ Ket } \\
\hline & SS & $\mathbf{S}$ & $\mathbf{K}$ & TS & STS & & & \\
\hline \multicolumn{9}{|c|}{ Reliabiity } \\
\hline X2.1.1 & 15 & 34 & 4 & 2 & 0 & 55 & 4.13 & B \\
\hline $\mathrm{X} 2.1 .2$ & 17 & 31 & 5 & 1 & 1 & 55 & 4.13 & B \\
\hline $\mathrm{X} 2.1 .3$ & 14 & 39 & 2 & 0 & 0 & 55 & 4.22 & SB \\
\hline Sub & 46 & 104 & 11 & 3 & 1 & 165 & 4.16 & B \\
\hline
\end{tabular}


JURNAL ILMIAH FEASIBLE: Bisnis, Kewirausahaan \& Koperasi, Vol.2.No.1 Februari 2020: 53-70

\begin{tabular}{|c|c|c|c|c|c|c|c|c|}
\hline \multirow{2}{*}{$\begin{array}{c}\text { Krite } \\
\text { ria }\end{array}$} & \multicolumn{5}{|c|}{ Jawaban Responden } & \multirow{2}{*}{ Jumlah } & \multirow{2}{*}{$\begin{array}{c}\text { Mean } \\
\text { Skor }\end{array}$} & \multirow{2}{*}{$\mathrm{Ke}$} \\
\hline & SS & $\mathbf{S}$ & $\mathbf{K}$ & TS & STS & & & \\
\hline \multicolumn{9}{|c|}{ Responsive } \\
\hline X2.2.1 & 15 & 35 & 5 & 0 & 0 & 55 & 4.18 & B \\
\hline X2.2.2 & 12 & 39 & 3 & 1 & 0 & 55 & 4.13 & B \\
\hline $\mathrm{X} 2.2 .3$ & 15 & 33 & 5 & 2 & 0 & 55 & 4.11 & B \\
\hline Sub & 42 & 107 & 13 & 3 & 0 & 165 & 4.14 & B \\
\hline \multicolumn{9}{|c|}{ Assurance } \\
\hline $\mathrm{X} 2.3 .1$ & 16 & 37 & 2 & 0 & 0 & 55 & 4.25 & SB \\
\hline $\mathrm{X} 2.3 .2$ & 12 & 41 & 2 & 0 & 0 & 55 & 4.18 & B \\
\hline $\mathrm{X} 2.3 .3$ & 19 & 36 & 0 & 0 & 0 & 55 & 4.35 & SB \\
\hline Sub & 47 & 114 & 4 & 0 & 0 & 165 & 4.26 & SB \\
\hline \multicolumn{9}{|c|}{ Emphaty } \\
\hline $\mathrm{X} 2.4 .1$ & 16 & 35 & 4 & 0 & 0 & 55 & 4.22 & SB \\
\hline $\mathrm{X} 2.4 .2$ & 24 & 31 & 0 & 0 & 0 & 55 & 4.44 & SB \\
\hline X2.4.3 & 10 & 39 & 5 & 1 & 0 & 55 & 4.05 & SB \\
\hline Sub & 50 & 105 & 9 & 1 & 0 & 165 & 4.24 & SB \\
\hline \multicolumn{9}{|c|}{ Tangible } \\
\hline $\mathrm{X} 2.5 .1$ & 15 & 37 & 2 & 1 & 0 & 55 & 4.20 & SB \\
\hline $\mathrm{X} 2.5 .2$ & 13 & 39 & 2 & 1 & 0 & 55 & 4.16 & B \\
\hline $\mathrm{X} 2.5 .3$ & 14 & 36 & 3 & 2 & 0 & 55 & 4.13 & B \\
\hline Sub & 42 & 112 & 7 & 4 & 0 & 165 & 4.16 & B \\
\hline Total & 227 & 542 & 44 & 11 & 1 & 825 & 4.19 & B \\
\hline
\end{tabular}

Tabel 1.12. Penilaian Variabel Kepuasan Pelanggan (Y)

\begin{tabular}{|l|c|c|c|c|c|c|c|c|}
\hline \multirow{2}{*}{$\begin{array}{c}\text { Krite } \\
\text { ria }\end{array}$} & \multicolumn{5}{|c|}{ Jawaban Responden } & \multirow{2}{*}{ Jumlah } & $\begin{array}{c}\text { Mean } \\
\text { Skor }\end{array}$ & Ket \\
\cline { 2 - 7 } & SS & S & K & TS & STS & & & \\
\hline Y1 & 13 & 40 & 2 & 0 & 0 & 55 & 4.20 & SB \\
\hline Y2 & 16 & 36 & 3 & 0 & 0 & 55 & 4.24 & SB \\
\hline Y3 & 18 & 35 & 2 & 0 & 0 & 55 & 4.29 & SB \\
\hline Total & $\mathbf{4 7}$ & $\mathbf{1 1 1}$ & $\mathbf{7}$ & $\mathbf{0}$ & $\mathbf{0}$ & $\mathbf{1 6 5}$ & $\mathbf{4 . 2 4}$ & SB \\
\hline
\end{tabular}

Dari Tabel di atas dapat dinyatakan bahwa ditinjau dari semua indikator variabel penetapan harga, kualitas pelayanan dan kepuasan pelanggan dapat dinyatakan baik dan sangat baik.

\section{Tingkat Penghunian Kamar}

Berdasarkan data tamu yang menginap selama tahun bulan Januari 2018 s.d. Mei

2019 dapat digambarkan tingkat penghunian kamar Wisma Universitas Terbuka sebagai berikut:

Tabel 1.13. Tingkat Penghunian Kamar Wiswa Universitas Terbuka

\begin{tabular}{|c|c|c|c|c|}
\hline No & Wisma & $\begin{array}{c}\text { Kapasitas } \\
\text { (org/hari) } \\
\text { *) }\end{array}$ & $\begin{array}{c}\text { Hunian } \\
\text { (org/hari) }\end{array}$ & $\begin{array}{c}\text { Tingkat } \\
\text { Hunian } \\
(\mathbf{\%})\end{array}$ \\
\hline & \multicolumn{4}{|c|}{ Tahun 2018 (12 bulan) } \\
\hline 1 & Wisma 1 & 16,896 & 459 & $2.72 \%$ \\
\hline 2 & Wisma 2 & 24,288 & 2,280 & $9.39 \%$ \\
\hline 3 & Wisma 3 & 25,344 & 1,195 & $4.72 \%$ \\
\hline & Keseluruhan & 66,528 & 3,934 & $\mathbf{5 . 9 1 \%}$ \\
\hline & \multicolumn{5}{|c|}{ Tahun 2019 (6 bulan) } \\
\hline 1 & Wisma 1 & 7,040 & 112 & $1.59 \%$ \\
\hline 2 & Wisma 2 & 10,120 & 699 & $6.91 \%$ \\
\hline 3 & Wisma 3 & 10,560 & 587 & $5.56 \%$ \\
\hline & Keseluruhan & 27,720 & 1,398 & $\mathbf{5 . 0 4 \%}$ \\
\hline
\end{tabular}

*) Asumsi dalam satu minggu dihitung rata-rata 5 hari.

Dari tabel 1.13 di atas dapat diartikan bahwa tingkat penghunian kamar Wisma Universitas Terbuka dinilai masih sangat rendah rata-rata setiap tahun berkisar antara 5\% s.d. 6\%. Menurut Badan Pusat Statistik (BPS) merilis tingkat penghunian kamar (TPK) hotel klasifikasi bintang di Indonesia pada Februari 2019 mencapai rata-rata 52,44 persen.

\section{Analisis Data Statistik}

1. Analisis Regresi Linear Berganda

Analisis regresi linier berganda digunakan untuk mengetahui adanya pengaruh variabel-variabel bebas (independen) terhadap variabel terikat (dependen). Dengan menggunakan aplikasi MS Excel, analysis tolls, regression diperoleh hasil sebagai berikut:

Tabel 1.14. Hasil Analisi Regresi Linier Berganda SUMMARY OUTPUT

\begin{tabular}{l|r}
\hline \multicolumn{2}{|c}{ Regression Statistics } \\
\hline Multiple R & 0.5859305 \\
\hline R Square & 0.3433145 \\
\hline Adjusted R Square & 0.3180574 \\
\hline Standard Error & 0.3762885 \\
\hline Observations & 55 \\
\hline
\end{tabular}


JURNAL ILMIAH FEASIBLE: Bisnis, Kewirausahaan \& Koperasi, Vol.2.No.1 Februari 2020: 53-70

\begin{tabular}{|l|r|r|r|r|r|}
\hline ANOVA & & & & & \\
\hline & df & \multicolumn{1}{c|}{ SS } & \multicolumn{1}{c|}{ MS } & F & Significance F \\
\hline Regression & 2 & 3.849284142 & 1.92464207 & 13.59278 & $1.7836 E-05$ \\
\hline Residual & 52 & 7.36283707 & 0.14159302 & & \\
\hline Total & 54 & 11.21212121 & & & \\
\hline
\end{tabular}

\begin{tabular}{lrrrrrr}
\hline & Coefficients & Standard Error & tStat & P-value & Lower 95\% \\
\hline Intercept & 1.359801 & 0.607561025 & 2.23813075 & 0.02952 & 0.14064062 \\
\hline X Variable 1 & -0.017588 & 0.135014322 & -0.1302651 & 0.896859 & -0.2885137 \\
\hline X Variable 2 & 0.7049319 & 0.15372125 & 4.5857802 & $2.885-05$ & 0.39646761 \\
\hline
\end{tabular}

Berdasarkan hasil analisis regresi berganda Tabel 1.14 di atas maka diperoleh Fungsi Regresi $\mathrm{Y}=1.360-0.018 \mathrm{X} 1+$ $0.705 \mathrm{X} 2$

\section{Uji Simultan (Uji F)}

Uji simultan (uji F) dilakukan untuk menguji ada tidaknya pengaruh variabelvariabel bebas (independen) secara simultan terhadap variabel terikat (dependen).

a) Berdasarkan hasil analisis Anova, diperoleh F-hitung =13.592

b) F-tabel dengan taraf kepercayaan $95 \%$ $\mathrm{DF} 1=2$ dan DF2 = 52 adalah 3.175.

c) F-hitung > F-tabel, maka dapat nyatakan bahwa variabel bebas yaitu tarif kamar (X1) dan kualitas pelayanan (X2) berpengaruh secara signifikan terhadap variabel terikat kepuasan pelanggan (Y) pada Wiswa Univrsitas Terbuka.

\section{Uji Parial (uji t)}

Uji parsial (uji t) digunakan untuk menguji apakah setiap variabel bebas yaitu penetapan tarif kamar (X1), dan kualitas pelayanan (X2) mempunyai pengaruh yang positif terhadap varibel terikat yaitu kepuasan pelanggan (Y) secara parsial. a) Berdasarkan hasil analisis regresi berganda Tabel 4.15 di atas maka diperoleh $\mathrm{t}$-hitung variabel $\mathrm{X} 1=-0.030$ dan t-hitung variabel X2 $=4.586$.

b) t-tabel dengan taraf kepercayaan $95 \%$ dengan DF 55-1 adalah 2.oo.

c) t-hitung variabel $\mathrm{X} 1<\mathrm{t}$-tabel sehingga variabel penetapan tarif kamar tidak berpengaruh secara signifikan terhadap varibel kepuasan pelanggan.

d) t-hitung variabel $\mathrm{X} 2>$ t-tabel sehingga variabel kualitas layanan berpengaruh secara signifikan terhadap variabel kepuasan pelanggan.

\section{Koefesien Determinasi (Adjusted R)}

Berdasarkan hasil analisis regresi berganda Tabel 4.15 diperoleh R-hitung sebesar 0.586, koefisien determinasi ( $R$ Square) adalah sebesar $0.586 \times 0.586=$ o.343. Dengan demikian maka dapat dinyatakan bahwa variabel bebas yaitu penetapan tarif kamar dan kualitas pelayanan berpengaruh terhadap variabel terikat kepuasan pelanggan sebesar 34\%, sedangkan sisanya (66\%) disebabkan oleh faktor lain yang tidak dimasukkan dalam studi ini.

\section{SIMPULAN}

\section{Kesimpulan}

Berdasarkan pembahasan dan hasil analisis data penetapan tarif kamar dan kualitas pelayanan terhadap kepuasan pelanggan pada Wisma Universitas Terbuka, dapat simpulan sebagai berikut: 
JURNAL ILMIAH FEASIBLE: Bisnis, Kewirausahaan \& Koperasi, Vol.2.No.1 Februari 2020: 53-70

1. Skor penilaian setiap indikator variabel bebas maupun variabel terikat berkisar antara 3.382 s.d. 4.436 dengan rata-rata baik setiap variabel. Oleh karena itu dapat disimpulkan bahwa aspek penetapan tarif sewa kamar, aspek kualitas pelayanan dan aspek kepuasan pelanggan pada Wisma Universitas Terbuka dapat dinyatakan sudah baik.

2. Berdasarkan analisis regresi berganda diperoleh persamaan regresi $\mathrm{Y}=1.360$ $0.018 \mathrm{X} 1+0.705 \mathrm{X} 2$ dan diperoleh angka F-hitung sebesar 13.592. Hal ini berarti bahwa secara sumultan terdapat pengaruh yang signifikan antara varibel penetapan tarif kamar dan kualitas pelayanan terhadap kepuasan pelanggan pada Wisma Universitas Terbuka.

3. Bedasarkan uji parsial (t-stat) menunjukkan bahwa variabel penetapan tarif sewa kamar tidak berpengaruh terhadap kepuasan pelanggan ( $\mathrm{t}$-hitung $=-0.030$ ), sedangkan variabel kualitas pelayanan berpengaruh secara signifikan terhadap kepuasan pelanggan (thitung = 4.586).

4. Berdasarkan analisis koefesien determinasi variabel penetapan tarif kamar dan kualitas pelayanan memiliki kontribusi $34 \%$ terhadap kepuasan pelanggan, sedangkan sisannya 66\% dipengaruhi oleh variabel lain.

5. Tingkat penghunian kamar (TPK) Wisma Universitas Terbuka dinilai masih sangat rendah berkisar 5-6\%, jauh di bawah angka rata TKP hotel bulan Februari 2019 sebesar 54,44\%.

\section{Saran}

1. Indikator kesesuaian harga/tarif sewa kamar dengan kualitas produk termasuk sudah baik namun perlu ditingkatkan menjadi sangat baik, demikian juga sistem pembayaran sewa agar lebih fleksibel dengan tetap memperhatikan unsur keamanan.

2. Indikator kualitas pelayanan pemberian perhatian khusus kepada setiap tamu yang menginap dinilai sudah baik namun indikator ini termasuk yang skornya paling rendah sehingga perlu ditingkatkan.

3. Kualitas pelayanan manajemen Wiswa Universitas Terbuka sangat berpengaruh terhadap kepusan pelanggan, oleh karenanya disarankan agar tetap dipertahankan dan bahkan ditingkatkan lagi menjadi sangat baik.

4. Tingkat penghunian kamar Wiswa Universias Terbuka masih termasuk sangat rendah, dan lokasi Wiswa Universitas Terbuka berada di dalam lingkungan kantor, disarankan agar kegiatan promosi dan kerjasama korporasi lebih ditingkatkan.

5. Perlu dilakukan penelitian lebih lanjut tentang analisis faktor yang mempengaruhi tingkat penghunian kamar Wisma Universitas Terbuka dalam rangka peningkatan pendapatan BLU. 
JURNAL ILMIAH FEASIBLE: Bisnis, Kewirausahaan \& Koperasi, Vol.2.No.1 Februari 2020: 53-70

\section{DAFTAR PUSTAKA}

Abdurahman dan Mudidin, 2011. Panduan Praktis Memahami Penelitian, Bandung: Pustaka Setia.

Abdurahman, Maman. 2011. Dasar-Dasar metode Statistika untuk Penelitian. Bandung : CV Pustaka Setia.

Agus Sulastiyono, 1999. Manajemen Penyelenggaraan Hotel, Alfabeta Bandung.

Agus Sulastiyono, Drs, M.si. 1999. Manajemen Penyelenggaraan Hotel. Alfabeta Bandung

Anwar, Suroyo. 2009. Pemahaman Individu, Observasi, Checklist, Interview,.Kuesioner dan Sosiometri. Yogyakarta: Pustaka Pelajar.

Ari Prasetio, Pengaruh Kualitas Pelayanan Dan Harga Terhadap Kepuasan Pelanggan,

http://journal.unnes.ac.id/sju/inde x.php/maj.

Arikunto, Suharsimi, Prosedur Penelitian Suatu Pendekatan Praktek, (Jakarta : PT Bina Aksara, 1989)

Basu Swastha Dharmmessta, 2016. Manajemen Pemasaran, Buku Materi Pokok Universitas Terbuka, Penerbit Universitas Terbuka, Edisi 2.

Boyd, Harper W, 2000. Manajemen pemasaran, Edisi Kedua, Erlangga, Jakarta.

Boyd, Harper W. dkk, (200o), Manajemen Pemasaran - Suatu Pendekatan
Strategis Dengan Orientasi Global edisi 2 jilid 2, Jakarta : Erlangga

Demetrius dan Kasmiruddin, Pengaruh Kebijakan Penetapan Tarif Kamar Hotel Terhadap Minat Konsumen, (Kasus Evaluasi Tingkat Hunian Kamar Hotel Mona Plaza). https://docplayer.info/33232477.

Dharmmesta dan Handoko. 2014. Manajemen Pemasaran Analisis Perilaku Konsumen. BPFEYogyakarta. Yogyakarta

Fandy Tjiptono, 2002. Manajemen Jasa, Penerbit ANDI Yogyakarta.

Fandy, Tjiptono. 2004. Manajemen Jasa, Edisi Pertama, Yogyakarta, Andi Offset

Ghozali, Imam. 2011. Aplikasi Analisis Multivariate Dengan Program SPSS. Semarang: Badan Penerbit Universitas Diponegoro.

Hadi, Sutrisno, 1989. Metodologi Research Jilid I \& II, Yogyakarta: Andi Offset. Husaini Usman dan Purnomo Setiady, Metodologi Penelitian Sosial, ( Jakarta : PT Bumi Aksara, 2006 )

Jogiyanto, H.M., 2005. Analisa dan Desain Sistem Informasi: Pendekatan Terstruktur Teori dan Praktik Aplikasi Bisnis, ANDI, Yogyakarta.

Jusniar Hutabarat, Analisis Hubungan Antara Tarif Pelayanan dan Kualitas Layanan Serta Pengaruhnya Terhadap Tingkat Kepuasan Kelompok Pasien Umum di Klinik “AN” Bandung, Universitas Komputer Indonesia, Program 
JURNAL ILMIAH FEASIBLE: Bisnis, Kewirausahaan \& Koperasi, Vol.2.No.1 Februari 2020: 53-70

Pascasarjana, Prodi Magister

Manajemen, UNPAD Bandung.

Kotler dan Keller, 2007. Manajemen

Pemasaran, Edisi 12, Jilid 1,

PT.Indeks, Jakarta.

Kotler Philip, 1995. Manajemen

Pemesaran, Implementasi, dan

Pengendalian, Penerbit Salemba

Empat, Analisis, Perencanaan, Edisi

Bahasa Indonesia Jakarta.

Kotler, Philip (2004). Marketing

Management, The Millenium

Edition. Englewood Cliffs, New

Jersey : Prentice Hall.

Kotler, Philip dan Keller K Lane, 2006.

Manajemen Pemasaran, Jakarta,

Ghalia, Indonesia.

Kotler, Philip, dan Armstrong, 2004.

Dasar-dasar Pemasaran, Edisi

Kesembilan, PT. Indeks, Jakarta.

Lumintang Intan Sintya, S. L. H. V. Joyce.

Lapian, Merlyn M. Karuntu,

Pengaruh Harga dan Kualitas

Layanan Terhadap Kepusan

Pelanggan Jasa Transportasi Gojek

Online pada mahasiswa FEB

Unsrat Manado, ISSN 2303-1174,

Fakultas Ekonomi dan Bisnis,

Universitas Sam Ratulangi Manado

Lupiyoadi, Rambat, 2001. Manajemen

Pemasaran Jasa, Jakarta: PT.

Salemba Empat.

Machfoedz, Mahmud, 2005. Pengantar

Pemasaran Moden, Yogyakarta, Upp AMP, Ykpn.
Modul IPWI, 1995. Strategi Bisnis Program

Pasca

SarjanaMagister

Manajemen, Badan Penerbit IPWI.

Mursid, M. 2014. Manajemen Pemasaran. Bumi Askara. Jakarta

Notoatmodjo, Soekidjo. (2005). Metodologi Penelitian Kesehatan (Edisi Revisi).

Jakarta : PT. Rineka Cipta.

Nursalam (2003). Konsep dan Penerapan

Metodologi Penelitian Ilmu

Keperawatan Pedoman Skripsi,

Tesis dan Instrumen Penelitian

Keperawatan. Jakarta : Salemba Medika.

Peraturan Pemerintah RI, Nomor 23 Tahun 2005, Tentang Pengelolaan

Keuangan Badan Layanan Umum, Sekretariat Negara RI.

Saladin, Djaslim, 2006, Manajemen Pemasaran, Edisi Keempat, Bandung : Linda Karya

Stanton, William J. (1981: 445) (2007). Manajemen Pemasaran dan Pemasaran Jasa, Bandung: Alfabeta.

Stanton, William, J, 1996. Prinsip Pemasaran, Edisi ketujuh, jilid 2, cetakan keempat. Gelora Aksara Pratama.

Sugiyono, 2012. Metode Penelitian Kuantitatif Kualitatif dan $R \& D$, Bandung: Alfabeta.

Sugiyono, 2013, Metodelogi Penelitian Kuantitatif, Kualitatif Dan $R \& D$. (Bandung: ALFABETA)

Sugiyono, 2005. Memahami Penelitian Kualitatif. Bandung: CV. Alfabeta. 
JURNAL ILMIAH FEASIBLE: Bisnis, Kewirausahaan \& Koperasi, Vol.2.No.1 Februari 2020: 53-70

Suroyo Anwar, 2009. Pemahaman Individu, Observasi, Checklist, Interview, Koesioner, dan Sosiometri, Yogyakarta: Pustaka Pelajar.

Tjiptono, Fandy 2002, Strategi Pemasaran, Yogyakarta, Penerbit Andi

Yusnani, Endang Sutrisna, Pengaruh kulaitas pelayanan dan penetapan harga terhadap kepuasan konsumen pengguna Jasa Umroh pada PT/ Silver Silk \& Travel, Prodi Administrasi Bisnis, Fakultas Ilmu Sosial dan Ilmu Politik. Universitas Riau, JOM FISIP Vol. 5: Edisi II Juli - Desember 2018. 